\title{
Vowel fronting, raising, and backing in Luzon and north-central Sulawesi
}

\author{
JASON WILLIAM LOBEL
}

\begin{abstract}
This article presents an overview of four shifts - low vowel fronting, low vowel backing, back vowel fronting, and mid vowel raising - found in a number of languages on or near the Pacific coast of Luzon in the Philippines and in northcentral Sulawesi in Indonesia. A more extensive illustration of low vowel fronting is given for Umiray Dumaget than has previously been made available, and a second, sporadic correspondence in Umiray Dumaget is shown to be only irregular and unconditioned. Interactions with Philippine-type morphology are also shown to result in synchronically productive alternations in Umiray Dumaget and several of the Mongondow-Gorontalo languages.
\end{abstract}

KEYWORDS

Philippines; Indonesia; Luzon; Sulawesi; vowel shifts; vowel raising; vowel fronting; vowel backing; phonology; historical linguistics.

\section{INTRODUCTION $^{1}$}

A handful of noteworthy vowel shifts can be found in Austronesian languages spoken in three distinct geographical areas: northern Sarawak, north-central

${ }^{1}$ Many thanks to my friends and consultants from the various ethnolinguistic groups represented in this article, as well as to Robert Blust, David Zorc, and William Hall for helpful comments on earlier drafts of this article. This article is dedicated to Thomas and Patricia Macleod, whose extensive unpublished documentation of the Umiray Dumaget language has provided numerous invaluable insights into its phonology and morphology.

JASON WILLIAM LOBEL is an Italian American linguist from southern California who received his doctorate in Linguistics in 2013 from the University of Hawai'i at Mānoa, with which he currently serves as an assistant adjunct professor. Since 1998, he has spent several thousand hours conducting fieldwork on over 250 Philippine and Philippine-type speech varieties in the Philippines, Indonesia, Malaysia, and Brunei. He is a three-time fellow of the US National Endowment for the Humanities for his work in northern Sulawesi, Indonesia, on the moribund Lolak language and the now-extinct Ponosakan. He also works as a language consultant for various projects, and is both a passionate supporter of indigenous rights, especially for the aboriginal Black Filipinos and other minority groups in insular Southeast Asia, and a lifelong advocate for the documentation, promotion, and preservation of endangered languages. Jason Lobel can be contacted at: lobel@hawaii.edu.

(C) 2021 Faculty of Humanities, Universitas Indonesia

JASON WILLIAM LOBEL | DOI: 10.17510/wacana.v22i1.1028. 
Sulawesi, and the Pacific coast of Luzon. While Robert A. Blust (2000, 2013, 2020) has discussed the shifts in the languages of the first area, those found in the other two areas have only been described in passing in miscellaneous publications (see Hunggu Tadjuddin Usup 1986; Lawrence A. Reid 1989, 1991; Ronald S. Himes 1998, 2002; Jason William Lobel 2010, 2013, 2021; Laura C. Robinson and Jason William Lobel 2013; Lobel et al. 2020). This article is intended to provide a consolidated overview of these shifts based on this author's own fieldwork on the languages in which they are found, providing greater detail than has previously been available, and paying special attention to the similarities and differences between their manifestation in each language, as well as to the synchronic alternations that occur in several of these languages due to interactions with their Philippine-type morphology. Note that the objective of this overview is simply to present the data and describe the details of the shifts under discussion, and that any conjecture about the underlying motivations for these innovations is beyond the scope of this article, but will be dealt with elsewhere (see Lobel et al. 2021).

\subsection{The Languages}

The languages of primary concern in this article, as illustrated in Map 1, are:

(a) The Northeastern Luzon languages, which include five languages spoken by aboriginal Black Filipino ${ }^{2}$ populations on or near the northeastern coast of the large northern Philippine island of Luzon (Dupaningan Agta, Pahanan Agta, Dinapigue Agta, Casiguran Agta, Nagtipunan Agta), plus the Paranan language of the non-aboriginal inhabitants of Palanan town (Robinson and Lobel 2013);

(b) Umiray Dumaget, a language spoken by an aboriginal Black Filipino population widely distributed throughout coastal and inland central Luzon (Himes 2002; Lobel 2013);

(c) Inagta Alabat and Manide, two closely-related languages spoken by aboriginal Black Filipinos in the central part of the southern peninsula of Luzon, which together form the Manide-Alabat branch (Lobel 2010, 2013) of the Philippine subgroup (see Blust 2019, 2021);

\footnotetext{
${ }^{2}$ Phlippine-born linguist Louward Zubiri notes that "Communities have registered both to [the] NCIP [National Commission on Indigenous Peoples] and DepEd [Department of Education] that they don't like the term Negrito" (pers. comm. 27-5-2020), sentiments also reported by Edith T. Mirante (2014). As such, the term negrito will be avoided in this article, especially since its most common use (including its feminine equivalent negrita) in Philippine languages is as a pejorative term not for aboriginal Black Filipinos, but for non-Black Filipinos with darkerthan-average skin tone.

${ }^{3}$ Note that Kasiguranin, the language of the non-aboriginal population native to the town centre of Casiguran, Aurora, originates from a Tagalog dialect that partially converged with neighbouring Agta languages belonging to the Northeastern Luzon subgroup, but is not genetically part of this subgroup. As such, Kasiguranin is not included in discussions of the Northeastern Luzon subgroup as all of its forms exhibiting low vowel fronting appear to be borrowings from neighbouring Agta languages.
} 
(d) Bolango, Bolangitang-Kaidipang, Suwawa, Gorontalo, and Buol, five members of the Gorontalic branch of Mongondow-Gorontalo languages spoken in northern Sulawesi (Usup 1986).

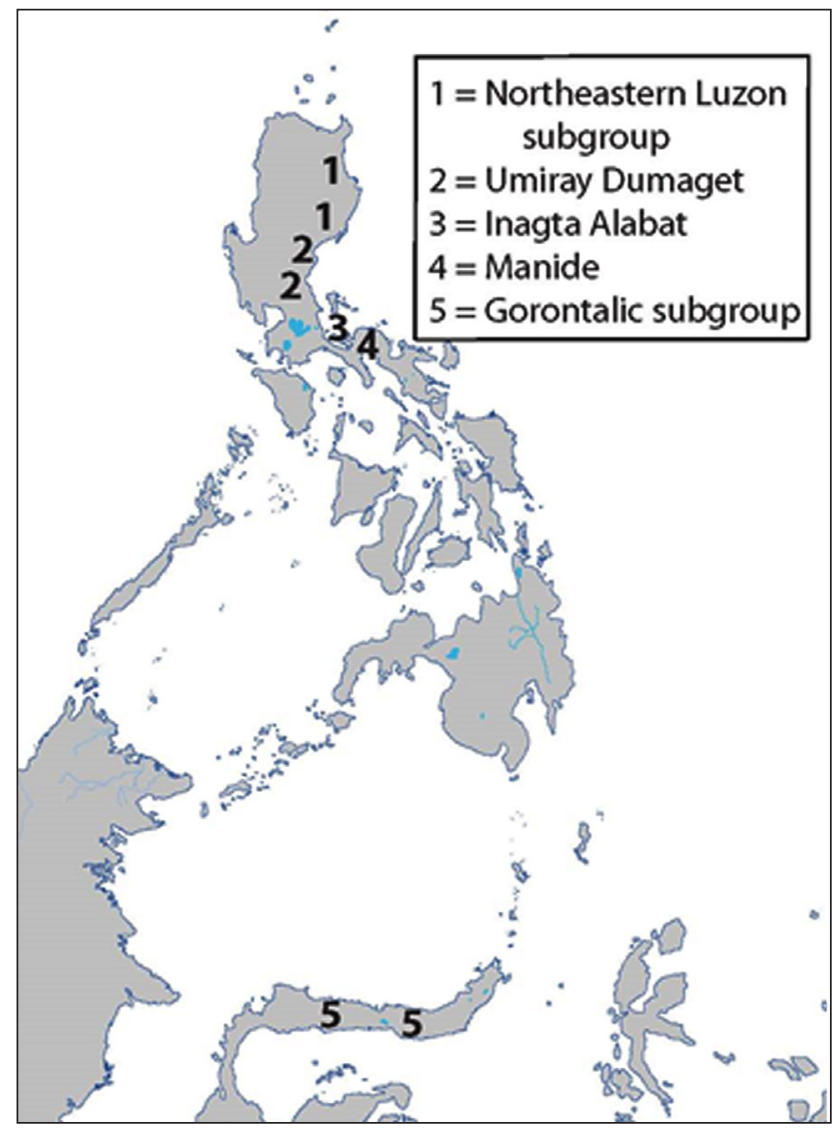

Map 1. Languages covered in this article.

\subsection{THE SHIFTS}

The following four phonological processes are covered by this article, all of which but the first involve the raising of a low or mid vowel.

(a) Back vowel fronting: the shift of * $u>/ i$, found only in Manide and Inagta Alabat (see Section 2);

(b) Mid vowel raising: the shift of ${ }^{*} \mathrm{O} / \mathrm{u} /$, found in Gorontalo, Buol, Bolango, Suwawa, and Bolangitang-Kaidipang (see Section 3.1);

(c) Low vowel backing: the shift of ${ }^{\mathrm{a}}>/ \mathrm{u} /$ in Manide, or *a $>/ \mathrm{o} /$ in Gorontalo, Buol, and Bolangitang-Kaidipang (see Section 3.2);

(d) Low vowel fronting: the shift of ${ }^{*} \mathrm{a}>$ /e/ or /i/ (depending on the language), by far the most widespread shift, found in Gorontalo as well as all of the aforementioned Black Filipino languages on or near the Pacific coast of Luzon (see Section 3.3). 
Note that despite the considerable differences between the shifts in the various languages in which they are present, one commonality is that they are all triggered by the voiced stops /b, d, g/ and, in Umiray Dumaget, Manide, and Inagta Alabat, the glides /w, y/ as well.

\section{BACK VOWEL FRONTING (BVF)}

The shift of ${ }^{*} \mathrm{u}>/ \mathrm{i} /$, herein referred to as back vowel fronting (BVF), is only found in Manide and Inagta Alabat, reflected in 28 forms in the former, and six forms in the latter. As with the other shifts found in these languages (low vowel fronting (LVF) and low vowel backing (LVB)), the small number of forms in which BVF is found is due first and foremost to its apparent antiquity, having likely been innovated some five or so hundred years ago, prior to more recent periods of largescale borrowing of Bisayan, Bikol, and Tagalog forms which entered Manide and Inagta Alabat after these vowel shifts had ceased to operate. In both languages, BVF can occur in any syllable and can be triggered by a voiced stop or glide, ${ }^{4}$ as shown in Table 1 . Note that vowel harmony in Inagta Alabat caused the subsequent lowering of the resulting penult vowel / $i$ / when the vowel of the following syllable was /e/, for example, behék / behék/ 'hair' (< PPH *buhák) 5 and beéye / beréye/ 'crocodile' (< PPH *buqáya) instead of the expected **bihék and **biéye, respectively.

It is unclear why so many fewer forms reflect BVF in Inagta Alabat than in Manide, although one possibility is that BVF operated for a shorter period of time in the former than in the latter. It is clear, however, that the Inagta Alabat forms with BVF were not simply borrowed from Manide, since certain forms reflect different sound changes in each language, such as Inagta Alabat beéye /be?éye/ 'crocodile' (< PPH *buqáya), with low vowel fronting in the final two syllables, where low vowel backing is found in its Manide equivalent, biúyu /bi?úyu/.

Finally, it should be noted that unlike some of the other shifts under discussion in this article, there are no synchronic alternations involving BVF (nor either of the other two shifts in Manide and Inagta Alabat).

\footnotetext{
4 Note that while no form reflecting BVF after / w/ has been found in either language, this is likely due to the relatively small data set available for both languages (approximately 2,000 items per language), as well as to the replacement of earlier forms which may have reflected this shift after / w/. However, since LVF and LVB occur after the set /b, d, g, w, y/, there is no reason to believe that BVF would have only operated after /b, d, g, y/ in Manide and Inagta Alabat but not /w/.

5 Unless noted otherwise, all $\mathrm{PGCPH}, \mathrm{PPH}$, and $\mathrm{PMP}$ reconstructions are from Robert A. Blust and Steve Trussel (2020), while PBis reconstructions are from R. David Zorc (1977, Ongoing) and PMA, PMoGo, and PGor reconstructions are my own. Forms reconstructable to ProtoAustronesian or Proto-Malayo-Polynesian are presented in their $\mathrm{PPH}$ forms in order to include word stress as well as to minimize unnecessary contrasts.
} 


\begin{tabular}{|c|c|c|c|c|}
\hline & TRIGGER & MANidE & InAGTa Alabat & $\begin{array}{l}\text { PROTO-FORM (PPH UNLESS } \\
\text { OTHERWISE INDICATED) }\end{array}$ \\
\hline \multirow[t]{6}{*}{ Вотн } & /b/ & $\begin{array}{l}\text { ambibíyi } \\
\text { /Pambibíyi/ }\end{array}$ & $\begin{array}{l}\text { ambibíyi } \\
\text { / Pambibíyi/ }\end{array}$ & *buyug 'bee' \\
\hline & & bihék / bihék/ & behék / behék/ & *buhək 'hair' \\
\hline & & bílan / bílan/ & bílan / bílan/ & *búlan 'moon' \\
\hline & & biúyu / birúyu/ & beéye /be?éye/ & *buqáya 'crocodile' \\
\hline & & bitáan / bitáPan/ & bitáan / bitáPan/ & $\begin{array}{l}\text { *butá?an 'the Grey's monitor } \\
\text { lizard' (Lobel) }\end{array}$ \\
\hline & $/ \mathrm{d} /, / \mathrm{g} /$ & digîl/digíî/ & digîl/digíî/ & PGCPH *dugú? ‘blood’ \\
\hline \multirow{21}{*}{$\begin{array}{l}\text { Manide } \\
\text { ONLY }\end{array}$} & /b/ & bébiy / bébiy/ & bébuy / bébuy/ & *bábuy 'pig' \\
\hline & & bíhì / bíhi?/ & búhù / búhu? / & $\begin{array}{l}\text { PMA *búhu? 'tracks } \\
\text { (as of water buffalo)' }\end{array}$ \\
\hline & & bignút / bignút/ & --- & $\begin{array}{l}\mathrm{PCPH}{ }^{*} \mathrm{~b}(\partial u)[\mathrm{R}] \text { nut 'pull out } \\
\text { hair or knife' }\end{array}$ \\
\hline & & bitág / bitág/ & butág / butág/ & PMA *butág ‘betel nut' \\
\hline & & Lábì /lábi?/ & Lábù /lábu?/ & $\begin{array}{l}\text { PMA *lábu? 'Labo River, } \\
\text { Mount Labo' }\end{array}$ \\
\hline & & tubí / tubí/ & tubú / tubú/ & *təbúh ‘sugarcane' \\
\hline & & ugbís / Pugbís/ & --- & *ugbús 'tip of growing plant' \\
\hline & /d/ & 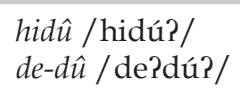 & 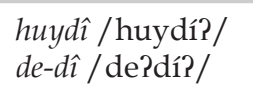 & $\begin{array}{l}\text { PMA *hu-ydú? 'that' } \\
\text { *da-du? 'there' }\end{array}$ \\
\hline & & ídì / Pídir / & ídù / Pídu?/ & ${ }^{*}$ qiduq 'dog' \\
\hline & & kuldít / kuldít/ & kuldút / kuldút/ & PMA *kuldút 'run' \\
\hline & & túdì / túdi?/ & --- & *túduq 'drip' \\
\hline & & tudî / tudí?/ & --- & *tudúq 'teach' \\
\hline & /g/ & be-gí / be?gí/ & be-gú / be?gú/ & *baqəRú 'new' \\
\hline & & demgî / demgíi/ & --- & PBis *damgu 'dream' \\
\hline & & $\begin{array}{l}\text { galú-gì } \\
\text { /galú?gi?/ }\end{array}$ & $\begin{array}{l}\text { gilú-gù } \\
\text { /gilú?gu?/ }\end{array}$ & PMA *galu?gu? 'fly (n.)' \\
\hline & & kúgin / kúgin/ & kúgun / kúgun/ & *kúRun 'cogon grass' (Zorc) \\
\hline & & súgì /súgi?/ & --- & *súRu? 'command' \\
\hline & & tágì /tági?/ & tágù / tágu?/ & *táRuq ‘hide' \\
\hline & & túgin / túgin/ & túgun / túgun/ & *túgun 'order, request' (Zorc) \\
\hline & /y/ & hayíg / hayíg/ & hayúg / hayúg/ & $\begin{array}{l}\text { PMA *hayúg ‘hunt for } \\
\text { monkeys' }\end{array}$ \\
\hline & & yi /yi/ & yu /yu/ & * $\mathrm{yu}$ '2PL.GEN' \\
\hline
\end{tabular}

Table 1. Back vowel fronting in Manide and Inagta Alabat. 


\section{VOWEL RAISING SHIFTS}

Unlike back vowel fronting, the three remaining vowel shifts involve the raising of a low or mid vowel: mid vowel raising (Section 3.1), low vowel backing (Section 3.2), and low vowel fronting (Section 3.3).

\subsection{MID VOWEL RAISING (MVR)}

The raising of ${ }^{*} \mathrm{O}>/ \mathrm{u} /$, herein referred to as mid vowel raising (MVR), is found in five of the seven members of the Gorontalic branch of MongondowGorontalo languages in north-central Sulawesi: Bolango, BolangitangKaidipang, Suwawa, Gorontalo, and Buol. However, since the shift is not found in Lolak (James N. Sneddon 1991; Jason William Lobel and Ade T. Paputungan 2017) or Bintauna, it cannot be reconstructed to Proto-Gorontalic, and therefore appears to be an areal feature. ${ }^{6}$ In all five languages where it occurs, MVR affects /o/ in any syllable of a root word after / b, d, g/, except in Suwawa, where it only occurs after /b/, as illustrated in Table 2.

\begin{tabular}{|c|c|c|c|c|c|c|c|}
\hline PMoGo & Bintauna & $\begin{array}{l}\text { BoLANGITANG- } \\
\text { KAIDIPANG }\end{array}$ & Bolango & SuWaWa & Gorontalo & BuOL & GLoss \\
\hline *bogas & bokaso & bugoso & bugaso & --- & --- & bugot & $\begin{array}{l}\text { 'uncooked } \\
\text { rice' }\end{array}$ \\
\hline *botiyos & bosiyoto & busiyoto & busiyoto & butiyoto & butiyoto & butiyot & 'calf (of leg)' \\
\hline *bonolan & -- & bulonga & bungol & bungola & bulonga & --- & 'ear' \\
\hline *boyol & bongolo & bungolo & bungolo & bungolo & bungolo & bungol & 'deaf' \\
\hline *bobai & $b o b a$ & -- & buba & -- & buwa & buway & ‘woman' \\
\hline *bokol & bo'olo & --- & bu'olo & bu'olo & bu'olo & -- & 'wave (n.)' \\
\hline *bobo & bobo & bubu & bubu & bubu & bubu & bubu & 'mute' \\
\hline *dodob & rorobo & dudubu & $d u d u b u$ & dodobo & --- & $d u d u b$ & 'chest' \\
\hline *bolotu & bolotu & -- & bulutu & bulotu & bulotu & --- & ‘boat' \\
\hline *bogat & -bokato & -bugoto & bugato & -bugato & -bubuheto & -bugot & 'heavy' \\
\hline $\begin{array}{l}\text { *donog } \\
{ }^{*} \text { mogole }\end{array}$ & $\begin{array}{l}\text {-rongoko } \\
\text { mokole }\end{array}$ & $\begin{array}{l}\text {-dungogu } \\
\text { mogule }\end{array}$ & $\begin{array}{l}\text {-dungogu } \\
\text { mogule }\end{array}$ & $\begin{array}{l}\text {-dongogo } \\
\text { mogole }\end{array}$ & $\begin{array}{l}\text {-dungohu } \\
\text { mohile }\end{array}$ & $\begin{array}{l}\text {-dungog } \\
\text { mogile }\end{array}$ & $\begin{array}{l}\text { 'hear' } \\
\text { 'request' }\end{array}$ \\
\hline
\end{tabular}

Table 2. Raising of *o in root words after voiced stops in Gorontalic languages.

A second environment where MVR occurs in Gorontalo, Bolango, and Bolangitang-Kaidipang is the paragogic /o/ which was added to earlier consonant-final root words in the Gorontalic languages (Sneddon and Usup 1986: 411), as illustrated in Table 3. In Suwawa, however, the paragogic -0 does not raise, and Buol does not generally reflect the paragogic vowel. It is also worth noting that paragogic $-o$ is realized as $/ \mathrm{u}$ / even after word-final ${ }^{*} \mathrm{~d}$ shifted to $/ \mathrm{r} /$ in Bolangitang-Kaidipang, as well as after word-final ${ }^{*} \mathrm{~g}$ shifted to $/ \mathrm{h} /$ in Gorontalo.

${ }^{6}$ Interestingly, this same raising of ${ }^{*} \mathrm{O}>/ \mathrm{u} /$ was also observed as a phonetic feature in the pronunciation of prepenultimate /o/ after /b, d, g/ in the speech of Ibrahim Tona (d. 2016), who was the last remaining fully-fluent speaker of Ponosakan (Lobel 2015, 2016), for instance, duhuwa 'two' (instead of expected dohuwa), bulotu 'boat' (instead of expected bolotu). 


\begin{tabular}{|c|c|c|c|c|c|c|}
\hline PMoGo & BINTAUNA & $\begin{array}{l}\text { BOLANGITANG- } \\
\text { KAIDIPANG }\end{array}$ & BOLANGO & SUWAWA & Gorontalo & GLoss \\
\hline *dodob & rorobo & $d u d u b u$ & dodobu & dodobo & --- & 'chest' \\
\hline *-uwab & $-u w a b o$ & $-u w a b u$ & $-u w a b u$ & $-u w a b o$ & $-u w a b u$ & ‘yawn' \\
\hline *-ilad & -ilaro & -ilaru & -iladu & -ilado & -iladu & 'dry in sun' \\
\hline *biyod & biyoro & --- & biyodu & biyodo & biyodu & 'fish eggs' \\
\hline *tulid & -- & tuliru & tulidu & tulido & tulidu & 'straight' \\
\hline *bukid & bu'iro & fukiru & $b u^{\prime} i d u$ & bu'ido & $h u^{\prime} i d u$ & 'mountain' \\
\hline *donog & -rongoko & -dungogu & -dungogu & -dongogo & -dungohu & 'hear' \\
\hline *bulig & buliko & fuligu & buligu & buligo & --- & $\begin{array}{l}\text { 'bunch of } \\
\text { bananas' }\end{array}$ \\
\hline *linug & --- & linugu & lindugu & linugo & lilihu & 'earthquake' \\
\hline *sarug & sauko & salugu & salugu & talugo & taluhu & ‘water’ \\
\hline *salog & saloko & (olagu) & salogu & --- & talohu & ‘floor’ \\
\hline *layag & leyako & --- & layagu & layago & layahu & ‘sail’’ \\
\hline
\end{tabular}

Table 3. Raising of paragogic -o after voiced stops in Gorontalic languages.

The only language in which MVR is known to result in synchronic alternations is Bolangitang-Kaidipang, where /g/-final prefixes mog-, nog-, and pog(reflexes of $\mathrm{PGCPH}$ *mag-, *nag- and *pag-, respectively) trigger raising when prefixed to a root whose initial segment is /o/, as illustrated in Table 4 with the roots -ombiyo 'clean up' and -otuto 'flatulence'.

\begin{tabular}{|c|c|c|c|c|}
\hline \multirow{4}{*}{$\begin{array}{l}\text { RoOT } \\
\text { ombiyo }\end{array}$} & \multirow{3}{*}{$\begin{array}{l}\text { BOLANGITANG-KAIDIPANG } \\
\text { mogumbiyo (AF.NPST) }\end{array}$} & & \multirow[b]{2}{*}{ PMoGo } & \\
\hline & & UNDERLYING & & \\
\hline & & *mog-ombiyo & *mog-om-piya & *mag-upiya \\
\hline & nogumbiyo (AF.PST) & *nog-ombiyo & *nog-om-piya & *nag-upiya \\
\hline \multirow{7}{*}{ otuto } & pogumbiyo (AF.IMP) & *pog-ombiyo & *pog-om-piya & *pag-upiya \\
\hline & ombiyo (OF.NPST) & *ombiyo-o(n) & *om-piya-on & *upiya-hən \\
\hline & niombiyo (OF.PST) & *ni-ombiyo & ${ }^{*}<$ in $>$ om-piya & $*<$ in $>$ upiya \\
\hline & mogututo (AF.NPST) & *mog-otuto & ${ }^{*}$ mog-otut & $*<$ um $>$ atut \\
\hline & nogututo (AF.PST) & *nog-otuto & *nog-otut & $*<$ in $><$ um $>$ otut \\
\hline & pogututo (AF.IMP) & *pog-otuto & *pog-otut & *atut \\
\hline & wotuto (n.) & *otuto & *otut & *otut \\
\hline
\end{tabular}

Table 4. Conjugations of Bolangitang-Kaidipang -ombiyo 'clean up' and -otuto 'flatulence'.

\subsection{LOW VOWEL BACKING (LVB)}

The low vowel backing shift is found in Manide as well as in three of the Gorontalic languages (Gorontalo, Buol, and Bolangitang-Kaidipang). In Manide, the earlier *a is always reflected as / $\mathrm{u} /$, as shown in Table 5 . 


\begin{tabular}{|c|c|c|c|}
\hline & MANIDE & РRоTO-Form & GLoss \\
\hline \multirow[t]{7}{*}{ /b/ } & biút / bi?út/ & PMA *bi?át & $\begin{array}{l}\text { 'carry on back w/ handles } \\
\text { in front' }\end{array}$ \\
\hline & biúyu /bi?úyu/ & PPH *buqáya & 'crocodile' \\
\hline & buyúg / buyúg/ & PPH *tabayaR & 'scrotum' \\
\hline & hagbúun /hagbú?un/ & PPH *hagbáPan (Lobel) & $\begin{array}{l}\text { 'Philippine Cuckoo-dove } \\
\text { (Macropygia tenuirostris)' }\end{array}$ \\
\hline & tigbús / tigbús/ & PPH *tigbas (Lobel) & $\begin{array}{l}\text { 'chop, hack at' (UDGT tigbés, } \\
\text { IRNC tigbas) }\end{array}$ \\
\hline & tilbud / tilbud/ & PMA *tilbad & ‘lie on one's side' \\
\hline & úbun / Púbun/ & PPH *qúban & 'grey hair' \\
\hline \multirow[t]{9}{*}{ /d/ } & dúmal /dúmal/ & $\begin{array}{l}\text { PMP * damaR (via Sama- } \\
\text { Bajaw damal) }\end{array}$ & 'pili nut tree resin' \\
\hline & hidú, didú / didú/ & PPH *sidá, *didá (Lobel) & '3PL.NOM', '3PL.OBL' \\
\hline & kildúp / kildúp/ & PMA *kildap & 'lightning' \\
\hline & mananagdúg /mananagdúg/ & PMA *mananagdag & 'alpha male monkey' \\
\hline & 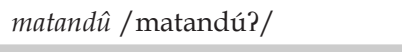 & PPH *tandaq & 'old (of males)’ (also 'learn') \\
\hline & $\begin{array}{l}\text { nadú / nadú/, di-dú / di?dú/, } \\
\text { hudú / hudú/ }\end{array}$ & PMA *na-dá, *di?-dá, *hu-dá & $\begin{array}{l}\text { 'where (past)', 'where } \\
\text { (nonpast)', 'which' }\end{array}$ \\
\hline & ngádun / yádun/ & PPH *ךájan & 'name' \\
\hline & tid̂ิ / tidú?/ & PPH *tídá(q) & 'remain' \\
\hline & tugdî /tugdú?/ & PMA *tugda? & 'spear' \\
\hline \multirow[t]{10}{*}{ /g/ } & ágù / Rágu?/ & $\mathrm{PPH}$ *qáRa & 'fig/balete tree (Ficus)' \\
\hline & anggugúmay / Pangugúmay/ & PMA * Pạgagámay & 'centipede' \\
\hline & degúw / degúw/ & PMA *degáw & 'day, sun' \\
\hline & egú / Pegú/ & $\mathrm{PCPH}$ * əgah & 'dry (adj.)' \\
\hline & esgúd / Pesgúd/ & PMA *?esgad & 'other side of (as mountain)' \\
\hline & guún /gu?ún/ & PMA *ga?an & 'fruit' \\
\hline & kagút / kagút/ & PPH *kaRát & 'bite' \\
\hline & lá-gù /lá?gu?/ & PPH *laqgaq & 'boil meat' \\
\hline & umágud / Pumágud/ & PBis *?<um>ágad & 'child-in-law' \\
\hline & umedús / Pumedús/ & PPH ${ }^{*}$ idas & 'sister-in-law' \\
\hline \multirow[t]{5}{*}{$/ \mathrm{w} /$} & anlaláwù / Panlaláwu?/ & $\begin{array}{l}\text { PPH *[]láwa? (via PMA } \\
\text { *?anlaláwa?) }\end{array}$ & 'spider' \\
\hline & híwù / híwu?/ & PPH *híwaq & 'slice' \\
\hline & íwug / Píwug/ & PCPH *híwag (Lobel) & 'move' \\
\hline & liwút /liwút/ & PCPH *liwát (Lobel) & 'repeat' \\
\hline & tiwúd / tiwúd/ & PPH *tuad (via PMA *tiwad) & 'bend over' \\
\hline \multirow[t]{5}{*}{ /y/ } & béyun / béyun/ & PMA *béyan & 'bone' \\
\hline & hiyú / hiyú/, diyú / diyú/ & PPH *siya, *diya (Lobel) & '3SG.NOM', '3SG.OBL' \\
\hline & 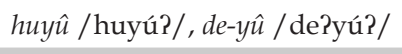 & PMA *huyá?, *da?yá? & 'that', 'there' (near addressee) \\
\hline & kíyut / kíyut/ & PMA *kíyat & 'rolling thunder' \\
\hline & lahíyu /lahíyu/ & $\begin{array}{l}\text { PMP *laqia (via Inabaknon } \\
\text { lahíya) }\end{array}$ & 'ginger' \\
\hline
\end{tabular}

Table 5. Low vowel backing in Manide. 
Note that like the other shifts in Manide and Inagta Alabat, LVB can spread through the glottal stop, as in biúyu 'crocodile' (< $\mathrm{PPH}^{*}$ buqáya), where the trigger for the backing of the vowel in the penult is not an immediately preceding stop, but instead, the onset of the preceding syllable, $/ \mathrm{b} /$. This same transparency can also be observed across morpheme boundaries in several suffixed forms, including Manide māhuyuún /ma:huyu?ún/, Inagta Alabat māhuye?én / ma:huye?én/ 'those (near addressee)' < PMA *mā-huya?-an; and Manide māhuydi?ún / ma:huydirún/'those (far from addressee)' < PMA *mā-huydu?-an. In both cases, the triggering effect of the earlier voiced stop or glide $(/ \mathrm{d} /$ or $/ \mathrm{y} /$ in these two cases, respectively) spreads through the intervening glottal stop, causing the *a of the suffix ${ }^{*}$-an to back to $/ \mathrm{u} / .^{7}$

The spreading behaviour of these shifts is quite complicated, in fact. First, the spread does not necessarily result in the same shift in each syllable: for example, in Manide biúyu /birúyu/ 'crocodile' (< *buqaya), the first syllable reflects BVF after / $\mathrm{b} /$ as expected, and the final syllable likewise reflects $L V B$ as expected after / y/, but the second syllable reflects LVB, even though it is triggered by the same word-initial /b/ which triggers BVF in the vowel immediately following it. Likewise, in the Inagta Alabat cognate beéye / be?éye/ 'crocodile', while the initial / b/ triggers BVF in the vowel immediately following it, and the /y/ LVF in the ultima, the LVF in the penult is in fact triggered by the same / b/ that triggers BVF a syllable earlier.

Note that while LVF is clearly permitted in penultimate syllables in Manide, it is prohibited from occurring in a syllable immediately preceding one in which LVB is found, thus buyúg 'scrotum' ( $<\mathrm{PPH}$ *tabayaR) instead of **beyug, biúyu 'crocodile' (< PPH *buqáya) instead of **bieyu, guún 'fruit' (< PMA *garán) instead of **geun, and hagbúun 'Philippine Cuckoo dove' (< $\mathrm{PPH}$ *hagbáPan) instead of **hagbeun. It should be noted that in the latter two forms, the LVB shift spreads from the trigger $-/ \mathrm{g} /$ and $/ \mathrm{b} /$, respectively - in the onset of the penult, through the glottal stop, to the vowel of the ultima, for which only LVB is permissible, not LVF. As such, since LVB is the only option for the ultima, and LVF cannot occur in a syllable immediately preceding one in which LVB occurs, the vowel of the penult also undergoes LVB. Note, however, that the sequence $/ \mathrm{eCu} /$ itself is not prohibited as long as the /e/ in the penult is not the result of LVF, for instance, Manide béyun 'bone' (<PMA *béyan) and déguw 'day, sun' (<PMA *dégaw), in which the vowel of the ultima is the product of $\mathrm{LVB}$, but the vowel of the penult reflects an earlier *e.

A final spreading pattern found in Manide (as well as in Inagta for LVF) is that observable in Manide biút / birút/, Inagta Alabat beét / be?ét/ 'carry on back with handles in front' (< PMA *birat), where the trigger - the wordinitial / b/ - does not cause a shift in the vowel / i/ immediately following it, but nevertheless triggers LVB in the ultima in Manide (LVF in Inagta Alabat), through the transparent intervening glottal stop.

7 In a single case, this transparency results in umlaut of *a > /e/ in Manide: $g u s e^{\prime} e k$ /guse?=ek/ 'I don't like it' from gusâ / gusa?/ 'doesn't like' + = ek /ek/ '1sG.NOM'. 
Unlike in Manide where it ceased to operate as a productive shift centuries ago, LVB is much more regularly reflected in the Gorontalic languages in which it is found - Buol and Bolangitang-Kaidipang - as illustrated in Table 6. In Gorontalo, however, LVB only occurs in the environment b_C(ui), for example, boli 'happen' < PMoGo *bali?, botu 'stone' < PPH *batú (Usup 1986).

PMoGo
*batu 'rock, stone'
*baloy 'house'
*bagu 'new'
*basa? 'wet'
*banun 'get up from lying down'
*bali? 'happen'
*dabu? 'fall, drop'
*dagat 'sea'
*undam 'medicine'
*dalan 'path'
*dasog 'transport'
*ugama 'crab sp.'
*ugas 'wash'
*bogan 'molar'
*bogas 'uncooked rice'
*togas 'hard (substance)'
*bogat 'heavy'
"ganu 'dry'
*dugan 'add'
*ga?an 'light (weight)'
*bogani 'brave'
*soga? 'light (n.)'

\begin{tabular}{ll} 
BolANGITANG- & BuOL \\
KAIDIPANG & \\
botu & botu \\
bole & bole \\
bogu & bogu \\
bosa & bota \\
bongu & bongun \\
boli & --- \\
dobu & dobu \\
--- & dogot \\
undomo & unom \\
dola & dolan \\
--- & dotog \\
--- & ugomo \\
ugoso & ugot \\
bogongo & bogong \\
bugoso & bugot \\
\hline-- & togot \\
bugoto & bugot \\
--- & gongu \\
dugongo & dugong \\
goo & goon \\
--- & bugoni \\
--- & togo
\end{tabular}

GorontaLO
botu
bele
bohu
bata
bongu
boli
dehu
deheto
wunamo
dalalo
detohu
uhemo
---
bohengo
---
toheto
buheto
hengu
duhengo
heelo
buheli
tohe

Table 6. Low vowel backing in Buol, Gorontalo, and Bolangitang-Kaidipang.

In the Gorontalic languages in which LVB occurs, prefixation with a reflex of /g/-final PGCPH prefixes *mag-, *nag-, *pag-, or *pinag- results in the synchronic backing of the initial / a/ of the underlying root, as illustrated in Table 7 for Buol (based on the root -ata 'sharpen, as a knife') and Table 8 for Bolangitang-Kaidipang (based on the roots-akut 'transport' and-ala'get, take').

BuOL
mogota (AF.NPST)
nogota (AF.PST)
pogota (AF.IMP)
ataan (LF.NPST)
niataan (LF.PST)
atae (LF.IMP)
pogotaan (LF.NPST)
pinogotaan (LF.PST)
pogota (IF.PST)
pinogota (IF.NPST)

$\begin{array}{ll}\text { UnderlyiNG } & \text { PMoGo } \\ \text { *mog-ata } & \text { *mog-asa? } \\ \text { *nog-ata } & \text { *nog-asa? } \\ \text { *pog-ata } & \text { *pog-asa? } \\ \text { *ata-an } & \text { *asa?-an } \\ \text { *ni-ata-an } & \text { * } \text { *in>asa?-an } \\ \text { *ata-e } & \text { *asa?-ay } \\ \text { *pog-ata-an } & \text { *pog-asa?-an } \\ \text { *pinog-ata-an } & \text { *pinog-asa?-an } \\ \text { *pog-ata } & \text { *pog-asa? } \\ \text { *pinog-ata } & \text { *pinog-asa? }\end{array}$

PGCPH
*mag-hása?
*nag-hása?
*pag-hása?
*hasá?-an
*h<in>asá?-an
*hasá?-i/ay
*pag-hasá?-an
*pinag-hasá?-an
*i-pag-hása?
*i-pinag-hása?

Table 7. Conjugations of Buol -ata 'sharpen, as a knife'. 


\begin{tabular}{|c|c|c|c|c|}
\hline \multirow[b]{2}{*}{ Root } & \multirow[b]{2}{*}{$\begin{array}{l}\text { BOLANGITANG- } \\
\text { KAIDIPANg }\end{array}$} & \multirow[b]{2}{*}{ UNDERLYING } & \multirow[b]{2}{*}{ PMoGo } & \multirow[b]{2}{*}{ PGCPH } \\
\hline & & & & \\
\hline -akuto & $\begin{array}{l}\text { mogokuto (AF.NPST) } \\
\text { nogokuto (AF.PST) } \\
\text { pogokuto (AF.IMP) } \\
\text { akuto (OF.NPST) } \\
\text { niakuto (OF.PST) } \\
\text { pogokuta (LF.NPST) } \\
\text { pinogokuta (LF.PST) }\end{array}$ & $\begin{array}{l}\text { *mog-akuto } \\
\text { "nog-akuto } \\
\text { *pog-akuto } \\
\text { *akuto } \\
\text { "ni-akuto } \\
\text { "pog-akut-a(n) } \\
\text { *pinog-akut-a(n) }\end{array}$ & $\begin{array}{l}\text { *mog-akut } \\
\text { *nog-akut } \\
\text { *pog-akut } \\
\text { *akut-on } \\
\text { *<in>akut } \\
\text { *pog-akut-an } \\
\text { *pinog-akut-an }\end{array}$ & $\begin{array}{l}\text { *mag-hákut } \\
\text { *nag-hákut } \\
\text { *pag-hákut } \\
\text { *hakút-ən } \\
\text { *h<in>ákut } \\
\text { *pag-hakút-an } \\
\text { *pinag-hakút-an }\end{array}$ \\
\hline -ala & $\begin{array}{l}\text { mogola (AF.NPST) } \\
\text { nogola (AF.PST) } \\
\text { pogola (AF.IMP) } \\
\text { ala (OF.NPST) } \\
\text { niala (OF.PST) } \\
\text { pogolaa (LF.NPST) } \\
\text { pinogolaa (LF.PST) } \\
\text { pogola (IF.NPST) } \\
\text { pinogola (IF.PST) }\end{array}$ & $\begin{array}{l}\text { *mog-ala } \\
\text { *nog-ala } \\
\text { "pog-ala } \\
\text { *ala } \\
\text { *ni-ala } \\
\text { *pog-ala-a(n) } \\
\text { *pinog-ala-a(n) } \\
\text { *pog-ala } \\
\text { *pinog-ala }\end{array}$ & $\begin{array}{l}\text { *mog-ala } \\
\text { *nog-ala } \\
\text { *pog-ala } \\
\text { *ala } \\
\text { *<in>ala } \\
\text { *pog-ala-an } \\
\text { *pinog-ala-an } \\
\text { *pog-ala } \\
\text { *pinog-ala }\end{array}$ & $\begin{array}{l}\text { *mag-ala[p] } \\
\text { *nag-ala[p] } \\
\text { *pag-ala[p] } \\
\text { *ala[p]-[ən] } \\
\text { *<in>ala[p] } \\
\text { *pag-ala[p]-an } \\
\text { *pinag-ala[p]-an } \\
\text { *i-pag-ala[p] } \\
\text { *i-pinag-ala[p] }\end{array}$ \\
\hline
\end{tabular}

Table 8. Conjugations of Bolangitang-Kaidipang -akuto 'escort' and -ala 'get, take'.

In Gorontalo, however, there are no productive alternations involving LVB, since the reflexes of * $\mathrm{g}$-final verb prefixes trigger low vowel fronting instead, as will be seen in Section 3.3.2.

\subsection{LOW VOWEL FRONTING (LVF)}

By far the most widespread of the shifts under discussion, low vowel fronting also has the greatest amount of variation from language to language.

(a) LVF is fully productive and consistently reflected after /b, d, g, w, y/ in the northern/coastal dialect of Umiray Dumaget, whereas in the southern/ highland dialect, it is only consistent after / b, d, g/, and less consistent after /w, y/ (see Section 3.3.1);

(b) LVF is synchronically productive in Gorontalo in certain environments (see Section 3.3.2);

(c) Far from being synchronically productive in Manide and Inagta Alabat, LVF appears to have been innovated several centuries ago (like BVF and LVB, see Sections 2 and 3.2), and ceased to operate prior to the last halfmillennium of borrowings from Tagalog, Spanish, Bikol, and an unknown early Bisayan language (see Section 3.3.3);

(d) LVF is also only inconsistently reflected in the Northeastern Luzon languages, where half of the forms that reflect it show disagreement from language to language (see Section 3.3.4);

(e) While LVF occurs after both voiced stops and glides in Umiray Dumaget, Manide, and Inagta Alabat, it only occurs after voiced stops in the Northeastern Luzon languages and Gorontalo, and has the additional restriction of not occurring after /b/ in Gorontalo if the vowel of the following syllable is [+high]. 


\subsubsection{Low vowel fronting in Umiray Dumaget ${ }^{8}$}

The most straightforward manifestation of low vowel fronting is in Umiray Dumaget, where it is fully productive, complete with synchronic alternations, unlike in the other languages under discussion. One environment where synchronic alternations occur is where infixation with $\langle-$ um- $>,<-i n-\rangle$, or <-umin-> blocks the raising effects of /b, $d, g, w, y /$, causing the /e/ in the first syllable of the root word to revert back to /a/, as illustrated in Table 9 with the roots getáng / getán/ 'buy' (< $\mathrm{PPH}^{*}(\mathrm{gR})$ átan), yedî /yedíi / 'do, make' (< TAG yári), beyéd / beyéd/ 'pay' (< $\mathrm{PPH}$ *báyad), and degdeg 'fall' (< $\mathrm{PPH}$ *dagdag). Likewise, as can be observed in the location focus forms of beyéd and degdeg in Table 9, the /a/ vowel of the location focus suffix -an raises to /e/ when suffixed to a root ending in $/ b, d, g, w, y /$.

Synchronic alternations involving LVF can also be observed in the actor focus future prefix $n \mathrm{~V}$ :- and its abilitative equivalent $n a k \mathrm{~V}:-$, in which $\mathrm{V}$ is a copy vowel of the underlying first vowel of the root word, and not simply a copy of the surface vowel. Therefore, /a:/appears in these prefixes corresponding to an /e/ in the first syllable of the root if that /e/ is the product of LVF, as illustrated in Table 10 (with forms with na- 'object focus abilitative past' and naka- 'actor focus abilitative past' included for comparison). On the other hand, /e: / appears as the copy vowel in these future affixes if the first vowel of the root is either / i/ or an /e/ which does not result from LVF, as in the roots lipâ /lipá?/ 'sit' and élag / Pélag/ 'avoid'.

8 This shift was first reported by Himes, who mentions that " $\mathrm{PPH}$ *a is reflected as a front vowel after a glide or after a voiced stop" (Himes 2002: 278), but neither provides any further details about the behaviour of this shift, nor comments on its presence in any of the other languages in which it is found. 


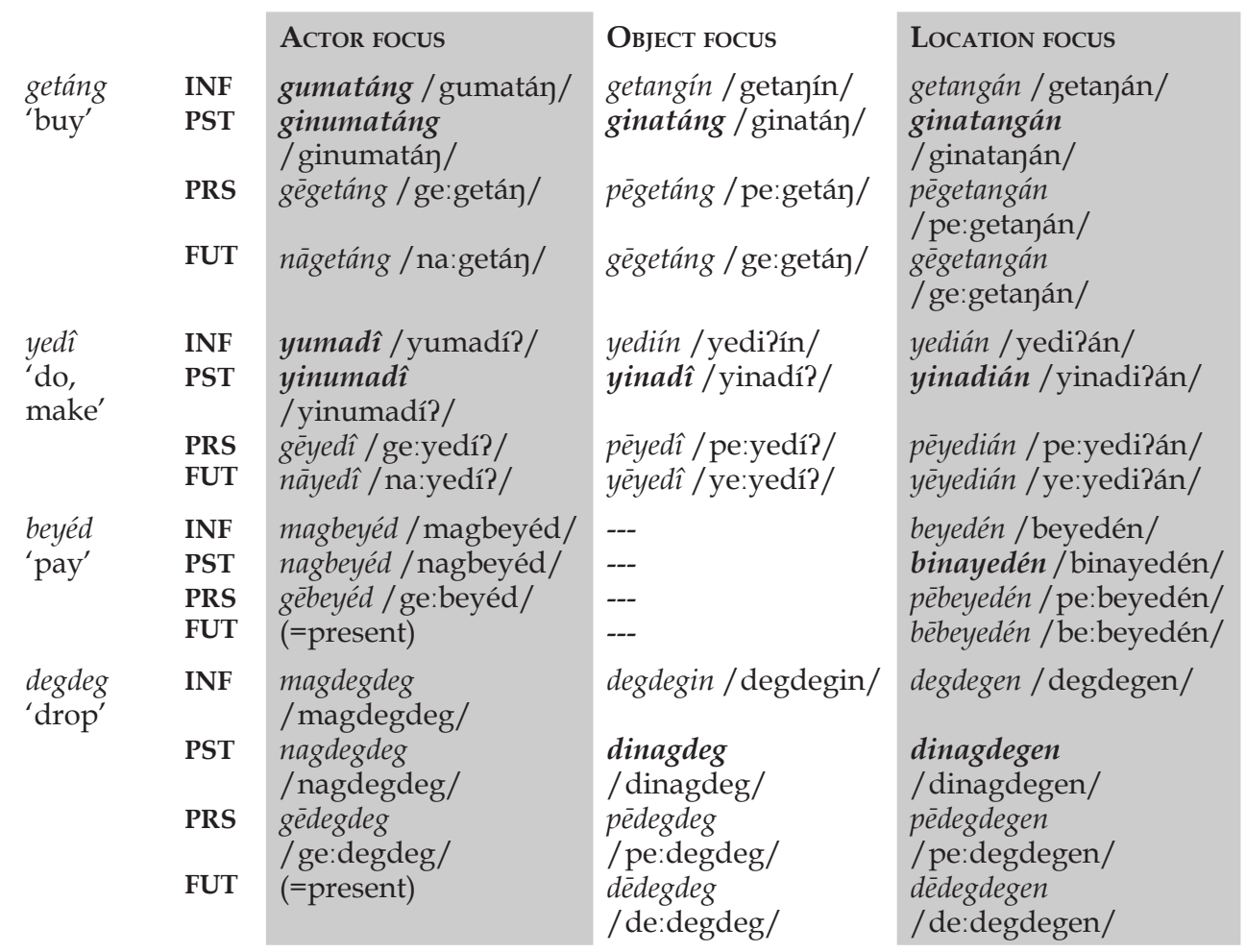

Table 9. Selected Umiray Dumaget verb conjugations.

\begin{tabular}{|c|c|c|c|c|}
\hline Rоoт & $n \mathrm{~V}:-($ AF.FUT) & $n a k \mathrm{~V}:-(\mathrm{AF} . \mathrm{ABIL.FUT})$ & $\begin{array}{l}n a-\text { (OF.ABIL.PST } \\
\text { or LF.ABIL.PST ) }\end{array}$ & $\begin{array}{l}\text { naka- } \\
\text { (AF.ABIL.PST) }\end{array}$ \\
\hline $\begin{array}{l}\text { detóng 'arrive' } \\
\text { getáng 'buy' } \\
\text { yedî'do, make' } \\
\text { élag 'avoid' } \\
\text { lipâ 'sit' }\end{array}$ & $\begin{array}{l}\text { nādetóng } \\
\text { /na:detóy/ } \\
\text { nāgetáng } \\
\text { / na:getáy/ } \\
\text { nāyedî̀ } \\
\text { / na:yedí?/ } \\
\text { néélag } \\
\text { /ne:Pélag/ } \\
\text { nēlipâa } \\
\text { /ne:lipá?/ }\end{array}$ & $\begin{array}{l}\text { nakādetóng } \\
\text { /naka:detón/ } \\
\text { nakāgetáng } \\
\text { /naka:getáy/ } \\
\text { nakāyedî̀ } \\
\text { /naka:yedí?/ } \\
\text { nakéélag } \\
\text { /nake:Pélag/ } \\
\text { nakēlipâa } \\
\text { /nake:lipá?/ }\end{array}$ & $\begin{array}{l}\text { nadetongán † } \\
\text { /nadetonán/ } \\
\text { nagetáng } \\
\text { / nagetán/ } \\
\text { nayedî } \\
\text { /nayedí?/ } \\
\text { naelágen † } \\
\text { / na?elágen/ } \\
\text { nalipaán † } \\
\text { /nalipa?án/ }\end{array}$ & $\begin{array}{l}\text { nakadetóng } \\
\text { /nakadetón/ } \\
\text { nakagetáng } \\
\text { /nakagetáy/ } \\
\text { nakayedî } \\
\text { /nakayedí?/ } \\
\text { nakaélag } \\
\text { /nakaPélag/ } \\
\text { nakalipâa } \\
\text { /nakalipá?/ }\end{array}$ \\
\hline
\end{tabular}

† denotes location focus forms with circumfix $n a-\ldots$-an

Table 10. Copy vowels in Umiray Dumaget forms prefixed with $n \mathrm{~V}$ :- 'actor focus future' and nakV:- 'actor focus abilitative future'.

Outside of the verb system, synchronic alternations can also be observed in nouns where an infix blocks LVF, for example, belóy / belóy / 'house' (<PPH *baláy), but binaloy-belóy / binaloybelóy/ 'housing area; area built up with homes' (not **bineloy-beloy); and wéli / wéli? / 'sibling' (< PPH *huaji), magwelî /magwelî́? / siblings (dual-reciprocal)', but magzwinalî / magwinalí?/'siblings (plural-reciprocal)' (not **magwinelî). 
Besides being reflected throughout the native lexicon of Umiray Dumaget, LVF is also consistently reflected in Spanish loanwords, for instance, beka 'cow' (< Span. vaca), tarabeho 'work' (< Span. trabajo), karsade 'street' (< Span. calzada), odes 'time, hour' (< Span. horas), biyehe 'voyage, trip' (<Span. viaje), tinde 'goods being sold' (<Span. tienda), and dibete 'debate' (<Span. debate).

Curiously, however, as noted earlier, while the shift is regularly reflected after $/ \mathrm{b}, \mathrm{d}, \mathrm{g} /$ in both the northern and southern dialects, it is only consistently reflected after the glides /w, y/ in the former, and much less regularly so in the latter. ${ }^{9}$ Table 11 illustrates forms where both dialects agree in fronting /a/ after /w/ and /y/, while Table 12 illustrates forms where /a/ is only fronted after these glides in the northern dialect.

\begin{tabular}{|c|c|c|c|}
\hline $\begin{array}{l}\text { PROTO-FORM (PPH UNLESS } \\
\text { OTHERWISE INDICATED) }\end{array}$ & $\begin{array}{l}\text { UMIRAY DUMAGET } \\
\text { (NORTHERN) }\end{array}$ & $\begin{array}{l}\text { UMIRAY DUMAGET } \\
\text { (SOUTHERN) }\end{array}$ & GLOss \\
\hline +batyag $\S$ & betyeg / betyeg/ & betyeg / betyeg/ & 'feel' \\
\hline *báyad & béyed / béyed/ & béyed / béyed/ & 'pay' \\
\hline +iwas $\ddagger$ & éwes / Péwes/ & éwes / Péwes/ & 'avoid' \\
\hline *kawayan & kawéyen / kawéyen/ & kawéyen / kawéyen/ & 'bamboo' \\
\hline *lawas § & lawés / lawés/ & lawés / lawés/ & 'body' \\
\hline +liwat $\S$ & liwét /liwét/ & liwét /liwét/ & 'repeat' \\
\hline${ }^{*}$ ma-bəR(ə)qat & mabbiyét / mabbiyét/ & mabbiyét / mabbiyét/ & 'heavy' \\
\hline *na-biha & nabiyég /nabiyég/ & nabiyég /nabiyég/ & 'full (sated)' \\
\hline +payag $\ddagger$ & páyeg / páyeg/ & páyeg / páyeg/ & 'agree, allow' \\
\hline+ puyat $\ddagger$ & poyét / poyét/ & puyét / puyét/ & 'stay up all night' \\
\hline +sagwan $\ddagger$ & sagwén / sagwén/ & sagwén / sagwén/ & 'oar' \\
\hline+ sibuyas $\dagger$ & sibúyes / sibúyes/ & sibúyes / sibúyes/ & 'onion' \\
\hline${ }^{*}$ tian & tíyen / tíyen/ & tíyen / tíyen/ & 'stomach' \\
\hline *tuad & towéd / towéd/ & towéd / towéd/ & 'bend over' \\
\hline *huaji (via * waji) & wélì / wéli?/ & wélì /wéli?/ & 'younger sibling' \\
\hline +walis $\ddagger$ & welís /welís/ & welís /welís/ & 'broom; sweep' \\
\hline +yadi $(<+$ jadi $)$ & yedî / yedî?/ & yedî /yedî?/ & 'do, make' \\
\hline
\end{tabular}

$\dagger$ : Loans from Spanish

‡: Likely loans from Tagalog

$\S$ : Likely loans from a Bisayan language

Table 11. Agreement in low vowel raising after glides in the northern and southern dialects of Umiray Dumaget.

\footnotetext{
${ }^{9}$ Note, however, that in the southern/highland dialect, whether or not LVF operates after /w /
} or $/ y /$ depends on each specific root, and is not simply the product of idiolectal variation. 


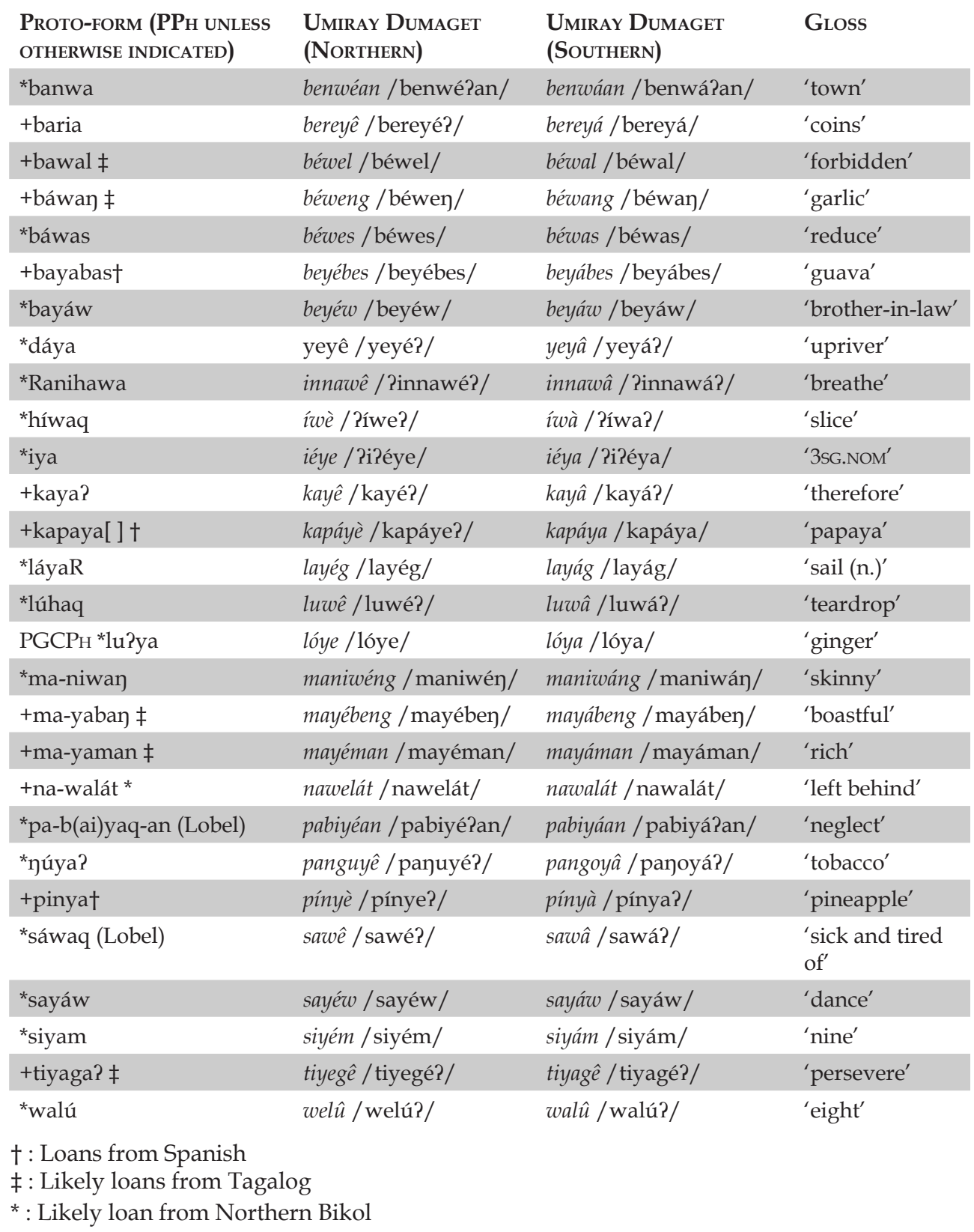

Table 12. Disagreement in low vowel raising after glides in the northern and southern dialects of Umiray Dumaget.

\subsubsection{Low vowel fronting in Gorontalo}

In Gorontalo, earlier *a is generally raised to /e/ after the voiced stops /b, $\mathrm{d}, \mathrm{g} /$, with the aforementioned exception (see Section 3.2) that the *a became $/ \mathrm{o} / \mathrm{after} / \mathrm{b} /$ if the vowel of the following syllable was [+high], as illustrated in Table 13. Note, however, that exceptions do also exist in which no shift is triggered at all despite being directly inherited from $\mathrm{PPH} / \mathrm{PMP}$, such as 
dalalo 'path' (< $\mathrm{PPH}_{\mathrm{H}}^{*}$ dálan) and bata 'wet' (< $\mathrm{PPH}^{*}$ basáq) instead of expected **delalo and **beta, respectively.

\begin{tabular}{|c|c|}
\hline GoRONTALO & PMoGo \\
\hline bele 'house' & *baloy \\
\hline bohengo 'molar' & *bogan \\
\hline bohu 'new' & *bagu \\
\hline boli'a 'happen' & *bali? \\
\hline bongu 'get up from lying down' & *bayun \\
\hline botu 'stone (n.)' & *batu \\
\hline buheli 'brave (adj.)' & *bogani \\
\hline buheto 'heavy' & *bogat \\
\hline deheto 'sea' & *dagat \\
\hline dehu 'fall (v.)' & *dabu? \\
\hline delomo 'deep' & *dalom \\
\hline detohu 'transport' & *dasog \\
\hline duhenga † 'add' & *dugan \\
\hline heelo 'light (adj.)' & *gaPan \\
\hline tohe 'light (n.)' & *soga? \\
\hline toheto 'hard (substance)' & *togas \\
\hline -uheto 'wash' & *ugas \\
\hline
\end{tabular}

$\dagger$ with location focus suffix $-a<*_{\text {-an }}$

Table 13. Low vowel raising and backing in Gorontalo.

It is noteworthy that there is synchronic LVF in Gorontalo when a root with word-initial /a/ is prefixed with reflexes of historically * $\mathrm{g}$-final prefixes such as moh- 'actor focus nonpast' (< $\mathrm{PGCPH}{ }^{*}$ mag-, PMoGo, PGoR *mog-), loh- 'actor focus past' (< PGCPH *nag-, PMoGo, PGoR *nog-), poh- 'non-actor focus nonpast' (PGCPH *pag-, PMoGo, PGoR *pog-) or piloh 'non-actor focus past' (< PGCPH *pinag-, PMoGo, PGoR *pinog-). This is illustrated in Tables 14 and 15, where the initial /a/ of the roots ${ }^{10}-a h u$ 'grab, snatch' and $-a^{\prime}$ upo 'catch, capture', respectively, is raised to /e/ when prefixed with moh-, loh-, poh-, and piloh-.

${ }^{10}$ Note that according to the phonotactics of Gorontalo, a facultative glide / $\mathrm{y} /$ is added to the beginning of words beginning with an underlying /i/, while /w/ is added as a facultative glide to words beginning with an underlying /a/, /o/, or /u/. However, no facultative glide is added for forms beginning with a glottal stop (for instance, 'ilowa'upa / ?ilowa?upa/, 'owa'upa / Powa?upa/) which itself is a reflex of earlier $/ \mathrm{k} /$. 


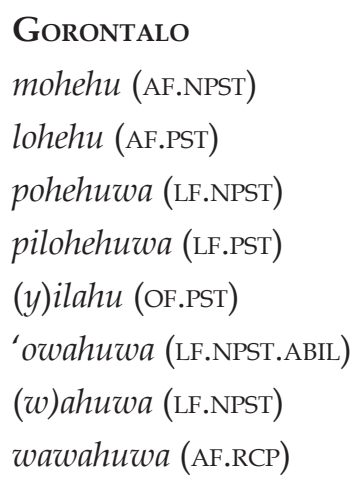

UNDERLYING
*moh-ahu
*loh-ahu
*poh-ahu-a
*piloh-ahu-a
*<il>ahu
*?o-ahu-a
*ahu-a
*a-ahu-a

PMoGo
*mog-agow
*nog-agow
*pog-agow-an
*pinog-agow-an
*<in>agow
*ko-agow-an
*agow-an
('CV-agaw-an)

PGCPH
*mag-agaw
*nag-agaw
*pag-agaw-an
*pinag-agaw-an
*<in>agaw
*ka-agaw-an
*agaw-an
(reciprocal of *agaw)

Table 14. Conjugated forms of Gorontalo -ahu 'grab, snatch'.

GorontALO
mohe'upo (AF.NPST)
lohe'upo (AF.PST)
(w)a'upa (LF.NPST)
(y)ila'upa (LF.PST)
(w)a'upo (OF.NPST)
(y)ila'upo (OF.PST)
'ilowa'upa (LF.PST.ABIL)
'owa'upa (LF.NPST.ABIL)

$\begin{array}{ll}\text { UnderLYING } & \text { PMoGo } \\ \text { *moh-aPupo } & \text { *mog-akup } \\ \text { *loh-a?upo } & \text { *nog-akup } \\ \text { *aPup-a } & \text { *akup-an } \\ \text { *<il>a?up-a } & \text { *<in>akup-an } \\ \text { *a?up-o } & \text { *akup-on } \\ \text { *<il>a'upo } & \text { *<in>akup } \\ \text { *2ilo-a'up-a } & \text { *kino-akup-an } \\ \text { *?o-a'up-a } & \text { *ko-akup-an }\end{array}$

PGCPH
*mag-()akup
*nag-()akup
*()akup-an
*()<in>akup-an
*()akup-ən
*()<in>akup
*kina-()akup-an
*ka-()akup-an

Table 15. Conjugated forms of Gorontalo - $a^{\prime} u p(o)$ 'catch, capture'.

Note that while reflexes of earlier * $\mathrm{g}$-final prefixes trigger synchronic LVF in Gorontalo, the insertion of infixes does not block earlier LVF in root words, unlike in Umiray Dumaget (see Section 3.3.1 and Table 9). In other words, a vowel /e/ which resulted from the raising of *a after reflexes of *b, ${ }^{*} \mathrm{~d}$, or * $\mathrm{g}$ in a Gorontalo root word does not revert to /a/ when an infix is placed between the vowel and the preceding trigger consonant, as illustrated in Table 16.

\begin{tabular}{|c|c|c|c|}
\hline \multirow{3}{*}{$\begin{array}{l}\text { ROOT WORD } \\
\text { he'uto 'close (a door)' }\end{array}$} & & \\
\hline & & & \\
\hline & hile'uta (LF.PST) & **hila'uta & ${ }^{*} \mathrm{~g}<$ in $>$ akut $[\mathrm{a}]$ (PGoR) \\
\hline de'upo 'catch, capture' & dile'upo (OF.PST) & **dila'upo & $* \mathrm{~d}<$ in $>$ akup \\
\hline delo 'bring' & dilelo (ОF.PST) & $* *$ dilalo & ${ }^{*} \mathrm{~d}<$ in $>$ ala \\
\hline detu 'sew' & diletu (OF.PST) & ** dilatu & *d<in>atum[o] (PGor) \\
\hline dehu 'drop' & dilehuwa (LF.PST) & **dilahuwa & $* \mathrm{~d}<\mathrm{in}>\mathrm{abu}$ Pan \\
\hline
\end{tabular}

Table 16. Lack of blocking of low vowel fronting in Gorontalo. 
Finally, note that synchronic alternations involving LVF also affect the location focus suffix $-a(<*$-an), which raises to $-e$ after $/ \mathrm{b}, \mathrm{d}, \mathrm{h} /$ (where /h/ is a reflex of earlier * $\mathrm{g}$, as previously mentioned), for example, pottuluhe 'bed; surface for sleeping on' < PMoGo *poCo-tulug-an.

\subsubsection{Low vowel fronting in Inagta Alabat and Manide}

Unlike in Umiray Dumaget, and, to a lesser extent, Gorontalo, LVF in Manide and Inagta Alabat appear to have been innovated, and subsequently ceased to operate productively, several centuries ago. While it is impossible to precisely date these events, it is likely that this period predated the Spanish occupation of the Philippine islands, as the earliest loans from Bisayan languages - Manide demgî /demgí? / 'dream' < PBIs *damgu, and Inagta Alabat umáged, Manide umágud'son/daughter-in-law' < PBis * ?umágad (see Zorc 1977) - entered these languages early enough to still feed into these rules, as did early Sama-Bajaw loans such as Manide lahiyu 'ginger' (see Inabaknon lahiya, PMP *laqia) and Inagta Alabat demal, Manide dumal 'pili nut tree resin' (likely an early loan from a Sama-Bajaw language such as Inabaknon with damal reflecting PMP *damaR, see Karen J. Allison 1994). However, none of these shifts operate on the much larger number of subsequent borrowings from a later Bisayan contact language that was in the area toward the beginning of the Spanish occupation of the Philippines (Lobel 2010, 2013; Lobel et al. 2020), ${ }^{11}$ nor on even the oldest Spanish borrowings, let alone on the much more recent borrowings from Bikol or Tagalog. As such, there is an even larger number of forms, presumably either borrowed or innovated after the vowel shifts ceased to operate, where *a and * $u$ do not raise, back, or front after /b, d, g, w, y/.

LVF is generally reflected in the same forms in Inagta Alabat and Manide (see Table 17), except in cases where (1) Manide has LVB instead, especially since Manide does not allow LVF in the ultima (see Section 3.2 and Table 18); (2) forms in the two languages are not cognates; or (3) a borrowing or innovation in one language has replaced an earlier form still found in the other language (for instance, Manide welâ 'none', replaced by the more recent borrowing wayâ in Inagta Alabat). Note, however, that a harmonization rule in Inagta Alabat causes an expected /i/ in penultimate syllables to instead be reflected as /e/ if the vowel of the ultima is /e/, such as keldép 'lightning' < PMA *kildap, umedés 'sister-in-law' $<$ PMA *?<um $>$ idas, kéyet 'rolling thunder' $<$ PMA *kíyat, héwè / héwe?/ 'slice' < PPH *híwaq, heyé '3sG.NOM' < PMA *hiya, tedê / tedé? / 'remain' < PPH *tidá(q), tewéd 'bend over' < PMA *tiwad, teyéw 'point (v.)' < PMA *tiyáw, beét / be?ét/ 'carry on one's back' < PMA *birát, beéye / be?éye/ 'crocodile' $<\mathrm{PPH}$ *buqáya (via intermediate *bilaya, reflecting

${ }^{11}$ In fact, doublets exist in some cases, as in the dual reflexes of PPH *baláy, where Manide, Inagta Alabat beléy 'native Agta/Manide hut' is clearly a direct inheritance, representing a native concept and having undergone LVF; while Manide, Inagta Alabat bayáy 'modern lowlander hut' is a clearly foreign concept, and lacks any of the vowel shifts under discussion here, besides reflecting an * $1>/ y /$ shift that never operated in either of these two languages. See Lobel (2010: 492-495) for a more detailed discussion of prehistoric borrowing by Manide and Inagta Alabat. 
BVF in the first syllable). Finally, although Manide generally has far fewer forms reflecting LVF than Inagta Alabat due to the preponderance of LVB in the former, Manide does nevertheless have a handful of forms with LVF not found in Inagta Alabat (Авт), for example, demgî / demgí? / 'dream' (Авт dalangit), welâ / welá?/ 'none' (Авт wayâ), békang 'bowl-legged' (Авт bákang sákang), behiún / behi?ún/ 'man' (Авт lalákì), and gépus 'handcuff or otherwise bind the wrists' (Авт gápus).

\begin{tabular}{|c|c|c|c|}
\hline Inagta Alabat & Manide & $\begin{array}{l}\text { PROTO FORM (PPH UNLESS } \\
\text { OTHERWISE INDICATED) }\end{array}$ & Gloss \\
\hline bébuy / bébuy/ & bébiy / bébiy/ & *bábuy & 'pig' \\
\hline be-gú / be?gú/ & be-gí / be?gí/ & ${ }^{*}$ baqəRu & 'new' \\
\hline beh-en / beh?en/ & beh-en / behPen/ & *bahaqən (Zorc) & 'sneeze' \\
\hline--- & behiún / behi?ún/ & PMA *bahi?an & $\begin{array}{l}\text { 'man' (see PMA *báhi? } \\
\text { ‘bow (n.)') }\end{array}$ \\
\hline--- & békang / békan/ & *bakan & 'bowl-legged' \\
\hline beléy /beléy/ & beléy / beléy/ & *baláy & $\begin{array}{l}\text { ‘house: traditional Agta/ } \\
\text { Manide hut' }\end{array}$ \\
\hline bélù / bélu?/ & bélù / bélu?/ & *balu & 'widow' \\
\hline bélud / bélud/ & bélud / bélud/ & *báluj & 'dove sp.' \\
\hline beság / beság/ & beság / beság/ & *básag & 'shattered' \\
\hline besî / besí?/ & bebesî / bebesíi / & *basáq & 'wet' \\
\hline betés / betés/ & betés / betés/ & *batás & 'waterfall' \\
\hline betû / betú?/ & betû / betú?/ & *batú & 'stone' \\
\hline--- & demgî /demgíî/ & PBIS *damgu & 'dream' \\
\hline detúng / detún/ & detúng / detún/ & *datən & 'arrive' \\
\hline--- & gépus / gépus/ & *Rápus (via PMA *gápus) & 'handcuff; bind the wrists' \\
\hline $\begin{array}{l}\text { hinakléwen } \\
\text { /hinakléwen/ }\end{array}$ & --- & $\begin{array}{l}\text { (with } \mathrm{PPH}^{*} \text {-an ‘location } \\
\text { focus suffix') }\end{array}$ & $\begin{array}{l}\text { 'area ahead of where one } \\
\text { currently is' }\end{array}$ \\
\hline lu-ye /lu?ye/ & --- & PGCPH *lu?ya & 'ginger' \\
\hline udébì / Pudébi?/ & udébì / Pudébi?/ & *Pudábi? (Lobel) & $\begin{array}{l}\text { 'wild yam sp. (Dioscorea } \\
\text { polystachya)' }\end{array}$ \\
\hline wédì / wédi?/ & wédì / wédi?/ & *huaji (via PMA *wádi?) & ‘younger sibling' \\
\hline--- & welâ / welár/ & *wadáq & $\begin{array}{l}\text { 'there isn't; none; } \\
\text { don't have' }\end{array}$ \\
\hline
\end{tabular}

Table 17. Low vowel fronting in Inagta Alabat and Manide. 


\begin{tabular}{|c|c|c|c|}
\hline Inagta Alabat & Manide & $\begin{array}{l}\text { PROTO FORM (PPH } \\
\text { UNLESS OTHERWISE } \\
\text { INDICATED) }\end{array}$ & Gloss \\
\hline ágè / Ráge?/ & ágù / Rágu?/ & *qáRa & 'fig tree' \\
\hline $\begin{array}{l}\text { anggegémay } \\
\text { / Pangegémay/ }\end{array}$ & $\begin{array}{l}\text { anggugúmay } \\
\text { /Paygugúmay/ }\end{array}$ & PMA *?angagámay & 'centipede' \\
\hline beéye / be?éye/ & biúyu /bi?úyu/ & *buqáya & 'crocodile' \\
\hline beét / be?ét/ & biút / birút/ & PMA *biجát & 'carry on one's back' \\
\hline béyen / béyen/ & béyun / béyun/ & PMA *béyan & 'bone' \\
\hline degéw / degéw / & degúw / degúw/ & PMA *degáw & 'day, sun' \\
\hline démal / démal/ & dúmal / dúmal/ & (Sama-Bajaw damal) & 'pili nut tree resin' \\
\hline esgéd / Pesgéd/ & esgúd / Pesgúd/ & PMA *?esgad & 'across from' \\
\hline geén / ge?én/ & guún /gưún/ & PMA *ga?án & 'fruit' \\
\hline gilú-gù /gilúrgu?/ & galú-gì /galúrgi?/ & PMA *galu?gu? & 'fly (n.)' \\
\hline hagbéen / hagbé?en/ & hagbúun /hagbú?un/ & *hagbáPan & $\begin{array}{l}\text { 'Emerald dove } \\
\text { (Chalcophaps indica)' }\end{array}$ \\
\hline héwè / héwe?/ & híwù / híwu?/ & *híwa? & 'slice' \\
\hline heyé / heyé/, deyé / deyé/ & $\begin{array}{l}\text { hiyú /hiyú/, diyú } \\
\text { /diyú/ }\end{array}$ & ${ }^{*}$ siya, *diya & $\begin{array}{l}\text { '3sG.NOM' (h-/s-initial); } \\
\text { '3sG.OBL' (d-initial) }\end{array}$ \\
\hline $\begin{array}{l}\text { hidehén / hidehén/, } \\
\text { dedehén / dedehén/ }\end{array}$ & $\begin{array}{l}\text { hidû /hidú?/, did̂ิu } \\
\text { /didú?/ }\end{array}$ & *sidá, *didá & $\begin{array}{l}\text { '3PL.NOM' (h-/s-initial); } \\
\text { '3PL.OBL' ( } d \text {-initial) }\end{array}$ \\
\hline kádè / káde?/ & kádù / kádu?/ & PMA *káda? & 'say' \\
\hline kagét / kagét/ & kagút / kagút/ & $\begin{array}{l}{ }^{*} \text { *kaRát (via PMA } \\
{ }^{*} \text { kagát) }\end{array}$ & ‘bite' \\
\hline keldép / keldép/ & kildúp / kildúp/ & PMA *kildáp & 'lightning' \\
\hline keyét / keyét/ & kiyút / kiyút/ & PMA *kiyát & 'rolling thunder' \\
\hline $\begin{array}{l}\text { mananagdég } \\
\text { /mananagdég/ }\end{array}$ & $\begin{array}{l}\text { mananagdúg } \\
\text { /mananagdúg/ }\end{array}$ & PMA *mananagdag & 'alpha male monkey' \\
\hline ngáden / yáden/ & ngádun / yádun/ & $\begin{array}{l}\text { *nájan (via PMA } \\
\text { *yádan) }\end{array}$ & 'name' \\
\hline tagêe / tagé?/ & taĝ̂u / tagú?/ & $\begin{array}{l}\text { *taRá? (via PMA } \\
\text { *tagá?) }\end{array}$ & 'hack at, as with a bolo' \\
\hline tedê /tedé?/ & tid̂ิ / tidú?/ & *tidá(q) & 'remain' \\
\hline telbéd / telbéd/ & tilbúd / tilbúd/ & PMA *tilbad & 'lie on one's side' \\
\hline tewéd / tewéd/ & tiwúd / tiwúd/ & *tuad & 'bend over' \\
\hline teyéw / teyéw/ & tiyúw / tiyúw/ & PMA *tiyaw & 'point (v.)' \\
\hline tugdê / tugdé?/ & tugdî /tugdú?/ & PMA *tugda? & 'spear' \\
\hline úben / Púben/ & úbun / Púbun/ & *qúban & 'grey hair' \\
\hline umáged / Pumáged/ & umágud / Pumágud/ & PBIS *?<um>ágad & 'child-in-law' \\
\hline umedés / Pumedés/ & umedús / Pumedús/ & $\begin{array}{l}\text { *idás (via PMA } \\
{ }^{*} \text { ?<um>idás) }\end{array}$ & 'co-sibling-in-law' \\
\hline$-y \hat{e} /$ ye?/ & $-y \hat{u} /$ yu?/ & PMA *-ya? & $\begin{array}{l}\text { 'demonstrative base } \\
\text { indicating location near } \\
\text { addressee' }\end{array}$ \\
\hline
\end{tabular}

Table 18. Competing vowel shift in Inagta Alabat and Manide. 
Like the other previously-discussed shifts in Manide and Inagta Alabat, LVF spreads through / ?/ and /h/ in Inagta Alabat, as shown in Table 19 with cognate forms reflecting low vowel backing in Manide.

\begin{tabular}{|c|c|c|c|}
\hline Inagta Alabat & Manide & PMA & GLoss \\
\hline beét / be?ét/ & biút / birút/ & *bi?at & 'carry on one's back' \\
\hline beéye / be?éye/ & biúyu /bi?úyu/ & *buجáya & 'crocodile' \\
\hline geén / ge?én/ & guún / gưún/ & *ga?án & 'fruit' \\
\hline hagbeen / hagbéPen/ & $\begin{array}{l}\text { hagbuun } \\
\text { /hagbú?un/ }\end{array}$ & *hagbáPan & $\begin{array}{l}\text { ‘Philippine Cuckoo-dove } \\
\text { (Macropygia tenuirostris)' }\end{array}$ \\
\hline hidehén / hidehén/ & --- & *hidah-án & '3PL.NOM' \\
\hline $\begin{array}{l}\text { māhiduén } \\
\text { /ma:hiduPén/ }\end{array}$ & $\begin{array}{l}\text { māhudiún } \\
\text { /ma:hudi?ún/ }\end{array}$ & *mā-hidu?-án & $\begin{array}{l}\text { 'those (far from both speaker } \\
\text { and addressee) (NOM)' }\end{array}$ \\
\hline $\begin{array}{l}\text { māhuyeén } \\
\text { /ma:huye?én/ }\end{array}$ & $\begin{array}{l}\text { māhuyuún } \\
\text { /ma:huyưún/ }\end{array}$ & *mā-huya?-án & 'those (near addressee) (NOM)' \\
\hline $\begin{array}{l}\text { māhuyihén } \\
\text { /ma:huyihén/ }\end{array}$ & --- & *mā-huyih-án & 'these (NOM)' \\
\hline--- & $\begin{array}{l}\text { nakatanduún } \\
\text { /nakatandu?ún/ }\end{array}$ & *naka-tanda?-án & 'learn (LF.PAST)' \\
\hline
\end{tabular}

Table 19. Spread of vowel shifts through / h/ and / $/$ in Inagta Alabat and Manide.

In contrast with Umiray Dumaget, infixation with <in> does not block LVF in Inagta Alabat, ${ }^{12}$ as illustrated in Table 20.

\begin{tabular}{|c|c|c|c|}
\hline Root & ATTESTED INFIXED FORM & UNDERLYING FORM & UNATTESTED \\
\hline be-gú / be-gú/ 'new' & bine-gú / bine?gú/ & $\mathrm{b}<\mathrm{in}>\mathrm{e}$ ?gu & **bina?gu \\
\hline beléy / beléy/ 'house' & bineléy-beléy / bineléy-beléy/ & b<in>eley-beley & **binaley-beley \\
\hline bésag / bésag/ 'shatter' & binésag / binésag/ & $\mathrm{b}<$ in $>$ esag & **binasag \\
\hline besî / besî́? / 'wet' & binesî / binesí? / & $\mathrm{b}<$ in $>$ esi? & **binasi? \\
\hline detúng / detúy/ 'arrive' & dumetúng / dumetún/ & $\mathrm{d}<$ um $>$ etung & ${ }^{* *}$ dumatung \\
\hline diyá / diyá/ 'bring' & diniyahán / diniyahán/ & $\mathrm{d}<$ in $>$ iyah-an & **dinayahan \\
\hline
\end{tabular}

Table 20. Infixed forms in Inagta Alabat.

Finally, note that at least one noun - Inagta Alabat hinaklewen $(<*$ $<<$ in $>$ aklewan) 'area ahead of where one currently is' - provides evidence that at the time that LVF was still productive, the /a/ of location focus suffix *an was also prone to raising after the triggering consonants $/ b, d, g, w, y /$.

\subsubsection{Low vowel fronting in Northeastern Luzon}

Similar to the situation in Manide and Inagta Alabat, low vowel fronting is only sporadically attested in the Northeastern Luzon languages, with only $50 \%$ of

${ }^{12}$ Manide equivalents for the forms in Table 20 were not available, as infixes only rarely occur in the language, since ${ }^{*}<$ in $>$ has been replaced by $p i-\sim i$, and * $<$ um $>$ functions only as an imperative. 
the forms that reflect LVF in at least one member of the subgroup reflecting it in all of the other members, as illustrated in Table 21 (which includes Manide and Inagta Alabat for the sake of comparison). ${ }^{13}$

\begin{tabular}{|c|c|c|c|c|c|c|}
\hline $\begin{array}{l}\text { PROTO-FORM (PPH UNLESS } \\
\text { OTHERWISE INDICATED) }\end{array}$ & Dup $†$ & $\mathbf{P}_{\mathrm{AH}}$ & CAS, NAG & $\mathbf{P A R}_{\mathrm{AR}}$ & MdE & Авт \\
\hline *baqəRu 'new' & bigú & bigú & bigú & bigú & bergí & be?gú \\
\hline *básag 'shattered' & bisag & biság & biság & biság & bésag & bésag \\
\hline *dáRaq 'blood' & digí? & digé? & $\begin{array}{l}\text { digé? (CAS) } \\
\text { digí? (NAG) }\end{array}$ & digí & $\operatorname{dig} \hat{\imath}$ & $\operatorname{dig} \hat{\imath}$ \\
\hline *baláy 'house' & biláy & biláy & bile (CAS) & biláy & beléy & beléy \\
\hline *bálu 'widow' & bilú? & biló? & $\begin{array}{l}\text { biló? (CAS) } \\
\text { bilú? (NAG) }\end{array}$ & bilú & bélu? & bélu? \\
\hline *basáq 'wet' & bésa & bisá? & bisá? & bisá? & bebesi? & besí? \\
\hline *sidá '3PL.NOM' & hidí & hide & $\begin{array}{l}\text { side (CAS) } \\
\text { sidi? (NAG) }\end{array}$ & hidi? & hidú & hedehen \\
\hline *dáRat 'sea' & digét & digit & $\begin{array}{l}\text { digét (CAS) } \\
\text { digít (NAG) }\end{array}$ & digét & dagat & dagat \\
\hline *haRəzán 'ladder, stairs' & ágden & agdénan & $\begin{array}{l}\text { agdénan(CAs) } \\
\text { ágen (NAG) }\end{array}$ & agdénan & hagdan & hagdan \\
\hline *tabáq 'fat' & tabí? & tabî? & tabí? & tabí? & --- & matabá? \\
\hline *dakə́p 'catch' & dakkap & dikáp & dikap & dikáp & dakep & -- \\
\hline *bəRás 'uncooked rice' & bagah & baggés & bagís & baggés & bagás & bugás \\
\hline *dakól 'large' & dakal & dakól & díkkal & dikál & dakú? & damakú? \\
\hline *húRas 'wash' & ugés & ugés & $\begin{array}{l}\text { ugés (CAS) } \\
\text { ugás (NAG) }\end{array}$ & ugás & hugas & hugas \\
\hline *batú 'stone' & bitú? & bitú? & bitú? & batú & betú? & betú? \\
\hline *kaRát 'bite' & kaget & kagét & kagét & kagát & kagút & kagét \\
\hline *báyu 'pound rice' & biyu? & báyyu? & biyú? & báyo & bayú & bayú \\
\hline *baháR 'loincloth' & beeg & bareg & biig & bareg & bahág & bahág \\
\hline *nájan 'name' & nagen & yahán & yahén & yarán & yádun & yáden \\
\hline *gatáq 'coconut milk' & gittá? & gatá? & gatá? & gatá? & gatá? & gatá? \\
\hline *huaji 'sibling' & wadí? & wadi? & wadí? & wadi? & wédi? & wédi? \\
\hline *dáhun 'leaf' & doon & dáron & $\begin{array}{l}\text { dorón (CAS) } \\
\text { doon (NAG) }\end{array}$ & dú?un & dáhun & dáhun \\
\hline *baRiuh 'typhoon' & bágyo & bágyo & bágyo & bágyu & -- & bágyu? \\
\hline *bábuy 'pig' & babúy & babúy & babúy & babúy & bebíy & bébuy \\
\hline *dadáh (Zorc) 'bring' & (tawéd) & (tawid) & (tawíd) & (tawíd) & deyá & diyá \\
\hline *datón 'arrive' & (démat) & (démat) & (démat) & (démat) & detúng & detúng \\
\hline
\end{tabular}

† DuP $=$ Dupaningan Agta; $\mathrm{PAH}=$ Pahanan Agta; $\mathrm{PAR}=$ Paranan; CAS = Casiguran Agta; NAG = Nagtipunan Agta; $\mathrm{MDE}=$ Manide; $\mathrm{ABT}=$ Inagta Alabat .

Table 21. Low vowel fronting in Manide, Inagta Alabat, and the NELuzon languages.

${ }^{13}$ Note that Dinapigue Agta, for which only a smaller set of data is available, is not included in Table 21, but generally patterns with Pahanan Agta. 
Note that one key difference is that LVF is only reflected in Northeastern Luzon languages after voiced stops / b, d, g/ , unlike Inagta Alabat, Manide, and Umiray Dumaget, where this shift also occurred after glides. Furthermore, where cognates are present, half of the forms with LVF in at least one NELUZON language do not reflect any vowel shift in their Manide and Inagta Alabat cognates.

Also, in contrast with the behaviour of LVF in Umiray Dumaget, infixation with <um> and <in> does not block the fronting effects of /b, d, g/ in Northeastern Luzon languages, as illustrated for Casiguran Agta and Paranan in Table 22.

\begin{tabular}{|c|c|c|c|c|}
\hline \multirow{3}{*}{ Casiguran Agta } & & $\mathbf{P P H}_{\mathbf{H}}$ & & UNATTESTED \\
\hline & dikəp & *dakóp & nanikəp 'catch' (naN-dikəp) & **nanakəp \\
\hline & dikəp & *dakóp & dinikəp 'catch' (d<in>ikəp) & **dinakəp \\
\hline \multirow[t]{2}{*}{ Paranan } & dikəp & *dakóp & dinikəp 'catch' (d<in>ikəp) & **dinakəp \\
\hline & dikal & *dakól & dumikal 'grow larger' (d<um>ikəl) & **dinakəl \\
\hline
\end{tabular}

Table 22. Lack of synchronic alternations under infixation in Casiguran Agta and Paranan.

\section{Front VOWEL BACKING IN UMiray DUMAGET?}

In addition to the environmentally conditioned shifts discussed in the preceding sections, Himes (2002: 278) notes a handful of Umiray Dumaget lexical items (1)-(4) with /o/ in the ultima where /i/ would be expected.

(1) bukod 'mountain' (<PPH *búkij, expected **bukid): *i > /o/ after /k/

(2) langot 'sky' (<PPH *lánit, expected **langit): *i > /o/ after / y/

(3) putok 'land' (< $\mathrm{PPH}$ *pútik, expected ** putik): *i > /o/ after /t/

(4) tangos 'cry' (< PPH *tánis, expected **tangis): *i > /o/ after / y/

This $*_{i}>/ o /$ correspondence even appears to be the exact opposite of the ${ }^{*} \mathrm{O}>/ \mathrm{i} /$ correspondence found in a handful of forms where /o/ would have been the expected reflex of *o in word-final syllables (Himes 2002: 278).

(5) apdis 'stinging pain' (< $\mathrm{PPH}^{*}$ hapəjəs, ${ }^{14}$ expected **apdos)

(6) banglis 'fragrant' (< PPH *bay(ə)lúh, expected **banglos)

(7) pusid 'navel' (< PPH *púsəj, expected ** pusod)

(8) unid 'flesh' (<PPH *qunój, expected **unod)

Lobel (2010: 489) mistakenly drew parallels between these exceedingly few forms reflecting correspondences of ${ }^{*} \mathrm{i}>/ \mathrm{o} /$ and ${ }^{*} \mathrm{O}>$ / $\mathrm{i}$ / in Umiray Dumaget, on the one hand, and the environmentally-conditioned low vowel fronting, low

14 Alternately, the Umiray Dumaget form may be a reflex of the doublet *hapəjis. 
vowel backing, and back vowel fronting shifts in Manide and Inagta Alabat. However, a closer look reveals that (1)-(8) reflect sporadic, unconditioned shifts that have nothing in common with the environmentally-conditioned vowel shifts discussed in this article, which are triggered by the voiced stops /b, d, g/ and, in some languages, glides / w, y/. As such, it is now clear that no "front vowel backing" shift exists in the Umiray Dumaget language, nor can the appearance of /i/ instead of /o/ in forms (5)-(8) be considered a "back vowel fronting" shift, since these irregular correspondences are limited to only four lexical items, and are not environmentally conditioned, with one each occurring after $/ \mathrm{d} /, / 1 /, / \mathrm{s} /$, and $/ \mathrm{n} /$.

\section{CONCLUSION}

There are a number of interesting and intriguing aspects of the vowel shifts discussed in this article, a summary of which is provided in Table 23.

\begin{tabular}{|c|c|c|c|c|c|c|c|}
\hline & $\begin{array}{l}\text { LVF } \\
/ \mathrm{b}, \mathrm{d}, \mathrm{g} /\end{array}$ & $\begin{array}{l}\text { LVF } \\
/ \mathrm{w}, \mathrm{y} /\end{array}$ & $\begin{array}{l}\text { BVF } \\
/ \mathrm{b} /\end{array}$ & $\begin{array}{l}\text { BVF } \\
/ \mathrm{d}, \mathrm{g}, \mathrm{y} /\end{array}$ & $\begin{array}{l}\text { LVB } \\
/ \mathrm{b}, \mathrm{d}, \mathrm{g} /\end{array}$ & $\begin{array}{l}\text { LVB } \\
/ \mathrm{w}, \mathrm{y} /\end{array}$ & $\begin{array}{l}\text { MVR } \\
/ \mathrm{b}, \mathrm{d}, \mathrm{g} /\end{array}$ \\
\hline NELuzon & + & - & - & - & - & - & - \\
\hline Umiray Dumaget & $+\dagger$ & - & - & - & - & - & - \\
\hline Inagta Alabat & + & + & + & - & - & - & - \\
\hline Manide & + & + & + & + & + & + & - \\
\hline SuWAWA & - & - & - & - & - & - & + \\
\hline BOLANGO & - & - & - & - & - & - & + \\
\hline BOLANGITANG-KAIDIPANG & - & - & - & - & $+\ddagger$ & - & $+\ddagger$ \\
\hline BuOL & - & - & - & - & $+\ddagger$ & - & + \\
\hline GoRONTALO & + & - & - & - & $+\ddagger$ & - & + \\
\hline
\end{tabular}

† Synchronically productive (both raising and blocking)

‡ Synchronically productive (raising but not blocking)

Table 23. Summary of vowel shifts in Pacific coastal Luzon and northern Sulawesi.

First, while the shifts are found in more-or-less contiguous areas in Luzon and in Sulawesi, the specific details of their manifestation in each individual language indicate that these shifts developed largely independently in virtually every language in which they occurred, albeit, at least in some cases, almost certainly while in contact with one another. Second, why the shifts in Luzon would be limited to languages spoken by aboriginal Black Filipino groups along the Pacific coast of Luzon (borrowed forms in non-aboriginal languages Kasiguranin and Paranan notwithstanding) is perplexing. In fact, the shifts are not found in the various Black Filipino languages located further away from the Pacific coast, such as Northern Alta, Central Cagayan Agta, and the Ayta and Atta languages, nor in those further south (for exampe, Inagta Partido and Inagta Rinconada further southeast in Luzon; Inata and Inete/ Inati ${ }^{15}$ in the Visayan Islands; and Mamanwa in Mindanao). Finally, further

\footnotetext{
${ }^{15}$ Inati, however, does exhibit the unconditioned raising of *a to /e/ ( [ $\left.\varepsilon\right]$ ) (F. Douglas Pennoyer
} 
investigation is clearly needed into the motivation for the raising, fronting, and backing of vowels after voiced stops and glides (see Lobel et al. 2021).

\section{AbBreViations}

\begin{tabular}{|c|c|}
\hline ABIL & abilitative/accidental \\
\hline Авт & Inagta Alabat \\
\hline adj. & adjective \\
\hline $\mathrm{AF}$ & actor focus \\
\hline BVF & back vowel fronting \\
\hline CAS & Casiguran Agta \\
\hline $\mathrm{CV}$ & consonant+vowel reduplication \\
\hline DuP & Dupaningan Agta \\
\hline FUT & future \\
\hline GEN & genitive \\
\hline IF & instrument focus \\
\hline IMP & imperative \\
\hline INF & infinitive \\
\hline IRNC & Inagta Rinconada \\
\hline LF & location focus \\
\hline LVB & low vowel backing \\
\hline LVF & low vowel fronting \\
\hline MDE & Manide \\
\hline MVR & mid vowel raising \\
\hline n. & noun \\
\hline NAG & Nagtipunan Agta \\
\hline NELUZON & Northeastern Luzon subgroup \\
\hline NOM & nominative \\
\hline NPST & nonpast \\
\hline OBL & oblique \\
\hline OF & object focus \\
\hline PAH & Pahanan Agta \\
\hline PAR & Paranan \\
\hline PBIS & Proto-Bisayan \\
\hline PCBIS & Proto-Central Bisayan \\
\hline $\mathrm{PCPH}$ & Proto-Central Philippines \\
\hline PGCPH & Proto-Greater Central Philippines \\
\hline PGOR & Proto-Gorontalic \\
\hline PL & plural \\
\hline PMA & Proto-Manide-Alabat \\
\hline PMOGO & Proto-Mongondow-Gorontalo \\
\hline PMP & Proto-Malayo-Polynesian \\
\hline PPH & Proto-Philippines \\
\hline PRS & present \\
\hline PST & past \\
\hline RCP & reciprocal \\
\hline
\end{tabular}

1986-1987), including in its own endonym, ete / Rete/, which derives from earlier *ata and was reinterpreted as ati / Pati/ by speakers of Bisayan languages, none of which have a phonemic /e/). 


$\begin{array}{ll}\text { SG } & \text { singular } \\ \text { Span. } & \text { Spanish } \\ \text { TAG } & \text { Tagalog } \\ \text { UDGT } & \text { Umiray Dumaget } \\ \text { v. } & \text { verb }\end{array}$

REFERENCES

Allison, Karen J. 1994. Sama Sibutu'-English dictionary, with ethnographic notes. Dallas, TX: SIL Archive of Language and Culture Data.

Blust, Robert A. 2000. "Low vowel fronting in northern Sarawak", Oceanic Linguistics 39: 285-319.

Blust, Robert A. 2013. The Austronesian languages. Canberra: Asia-Pacific Linguistics. [Second revised edition. Asia-Pacific Linguistics Open Access Monographs. Retrieved from: https:/ /openresearch-repository.anu.edu. au/bitstream/1885/10191/6/Blust-2013-AustronesianLanguages.pdf; accessed on 24-3-2021.]

Blust, Robert A. 2019. "The resurrection of Proto-Philippines", Oceanic Linguistics 58: 153-256.

Blust, Robert A. 2020. "More odd conditions? Voiced obstruents as triggers and suppressors in Miri, Sarawak", Phonology 37: 1-26.

Blust, Robert A. 2021. "Proto-Philippine Addenda; Theory, method, and data". [Unpublished ms. 85 pp.]

Blust, Robert A. and Steve Trussel. 2020. Austronesian comparative dictionary. [http://www.trussel2.com/ACD.]

Himes, Ronald S. 1998. "The southern Cordilleran group of Philippine languages", Oceanic Linguistics 37: 120-177.

Himes, Ronald S. 2002. "The relationship of Umiray Dumaget to other Philippine languages", Oceanic Linguistics 41: 275-294.

Lobel, Jason William. 2010. "Manide; An undescribed Philippine language", Oceanic Linguistics 49: 480-512.

Lobel, Jason William. 2013. Philippine and North Bornean languages; Issues in description, subgrouping, and reconstruction. PhD thesis, University of Hawai'i, Manoa.

Lobel, Jason William. 2015. "Ponosakan; A dying language of northern Sulawesi", Oceanic Linguistics 54(2): 396-435.

Lobel, Jason William. 2016. "Notes from the field: Ponosakan; The sounds of a silently dying language of Indonesia, with supporting audio", Language Documentation and Conservation 10: 394-423. [Retrieved from: http:// hdl. handle.net/10125/24700; accessed on 24-3-2020.]

Lobel, Jason William. 2021. “Umiray Dumaget; An underdocumented Philippine language". [Unpublished manuscript, 50 pp.]

Lobel, Jason William, Amy Jugueta Alpay, Rosie Susutin Barreno, and Emelinda Jugueta Barreno. 2020. "Inagta Alabat; A moribund Philippine language, with supporting audio", Language Documentation and Conservation 14: 1-57. 
[Retrieved from: http://hdl.handle.net/10125/24912; accessed on 24-32020.]

Lobel, Jason William, Robert A. Blust, and Erik Thomas. 2021. “Three puzzles for phonological theory in Philippine minority languages". [To appear in Oceanic Linguistics 60.]

Lobel, Jason William, and Ade T. Paputungan. 2017. "Notes from the field: Lolak; Another moribund language of Indonesia, with supporting audio", Language Documentation and Conservation 11: 328-363. [Retrieved from: http:/ / hdl.handle.net/10125/24758; accessed on 24-3-2020.]

Mirante, Edith T. 2014. The wind in the bamboo; A journey in search of Asia's "Negrito" indigenous people. Bangkok: Orchid Press.

Pennoyer, F. Douglas. 1986-1987. "Inati; The hidden Negrito language of Panay, Philippines", Philippine Journal of Linguistics 17(2)-18(1): 1-36.

Reid, Lawrence A. 1989. "Arta, another Philippine Negrito language", Oceanic Linguistics 28: 47-74.

Reid, Lawrence A. 1991. "The Alta languages of the Philippines", in: Ray Harlow (ed.), VICAL 2, Western Austronesian and contact languages; Papers from the Fifth International Conference on Austronesian Linguistics, pp. 265-297. Auckland: Linguistic Society of New Zealand and University of Auckland. [Te Reo Special Publication. ]

Robinson, Laura C. and Jason William Lobel. 2013. "The Northeastern Luzon subgroup of Philippine languages", Oceanic Linguistics 52: 125-168.

Sneddon, James N. 1991. "The position of Lolak", in: Ray Harlow (ed.), VICAL 2, Western Austronesian and contact languages; Papers from the Fifth International Conference on Austronesian Linguistics, pp. 299-318. Auckland: Linguistic Society of New Zealand and University of Auckland.

Sneddon, James N. and Hunggu Tadjuddin Usup. 1986. "Shared sound changes in the Gorontalic language group; Implications for subgrouping", Bijdragen tot de Taal-, Land- en Volkenkunde 142: 407-426.

Usup, Hunggu Tadjuddin. 1986. Rekonstruksi Protobahasa Gorontalo-Mongondow. PhD thesis, Universitas Indonesia.

Zorc, R. David. 1977. The Bisayan dialects of the Philippines; Subgrouping and reconstruction. Canberra: Pacific Linguistics.

Zorc, R. David. Ongoing. Zorc Data Sheets, Philippine Etyma. [Retrieved from: https://zorc.net/RDZorc/PHILIPPINE-ETYMA/.] 